\title{
The effect of varying the amount of linseed oil supplementation on rumen metabolism in sheep
}

\author{
BY O. A. IKWUEGBU* AND J. D. SUTTON \\ National Institute for Research in Dairying, Shinfield, Reading RG2 $9 A T$
}

(Received 28 October 1981-Accepted 2 April 1982)

1. The effects of three levels of linseed oil (LSO) supplementation of a basal diet on rumen digestion and flow of nutrients to the proximal duodenum of three mature sheep provided with permanent rumen and duodenal re-entrant cannulas were studied.

2. A basal diet of $200 \mathrm{~g}$ hay and $400 \mathrm{~g}$ concentrates daily, providing approximately $7.0 \mathrm{MJ}$ digestible energy and $13 \mathrm{~g} \mathrm{~N} / \mathrm{d}$, was given alone or with supplements of 13,26 or $40 \mathrm{ml} \mathrm{LSO} / \mathrm{d}$ in two equal portions at 06.00 and 18.00 hours. The flow of duodenal digesta was measured by spot-sampling using chromic oxide paper as the marker. Bacterial protein synthesis (BPS) was measured by the diaminopimelic acid technique.

3. Addition of LSO reduced the digestion of energy and organic matter, particularly acid-detergent fibre, in the stomach. Digestion in the intestines increased but at the higher levels of supplementation this failed to compensate completely for the reduction in rumen digestion. Total volatile fatty acid concentrations were not affected but molar proportions of acetate and butyrate were decreased by approximately 18 and $61 \%$ respectively while the molar proportion of propionate was increased twofold by the highest concentration of oil. The higher concentrations of LSO virtually eliminated protozoa from the rumen.

4. The second increment of LSO $(26 \mathrm{ml} / \mathrm{d})$ produced the highest duodenal flow of total $\mathrm{N}$ and bacterial $\mathrm{N}$ and the highest efficiency of BPS. The highest concentration of oil $(40 \mathrm{ml} / \mathrm{d})$ was without effect. Rumen and duodenal ammonia concentrations and plasma urea concentrations tended to be reduced by the higher concentrations of LSO.

5. It is argued that the results support suggestions made elsewhere that free oils reduce the efficiency of BPS but that they also reduce the numbers of protozoa which can cause an increase in the efficiency of BPS. The net effect of free oil supplementation on BPS is thus likely to be variable and difficult to predict.

Calculation of the feed requirements of ruminants for production is becoming increasingly dependerit on the ability to predict the supply of nutrients resulting from the processes of digestion and synthesis in the digestive tract in general and the rumen in particular. The inclusion in diets of certain supplements known to alter rumen processes introduces further complications which make the prediction of nutrient supply more difficult.

The addition of free linseed oil (LSO) or coconut oil to diets of hay and concentrates given to sheep was found by Knight et al. (1978) to increase markedly the amount and efficiency of microbial protein synthesis (MPS). On the other hand, no change was found in earlier studies when cod liver oil was used (Sutton et al. 1975) and Czerkawski et al. (1975) concluded that LSO caused microbial synthesis to be reduced. A more consistent response to free oil supplementation has been a reduction in the apparent digestion of organic matter $(\mathrm{OM})$ in the rumen $\left(\mathrm{ADOM}_{\mathrm{R}}\right.$ ) due mainly to a reduction in fibre digestion (Devendra \& Lewis, 1974; Kowalczyk et al. 1977; Knight et al. 1978). It seems probable that it is this reduction in digestion in the rumen that is the main factor limiting the amount of oil that can be added to ruminant diets. A further consequence is a reduction in the potential benefit, in terms of an increase in the absolute supply of microbial protein, resulting from any increase in the amount of microbial protein synthesised per unit $\mathrm{ADOM}_{R}$.

The purpose of the present experiment was to see if, by varying the amount of LSO supplement, it might be possible to explain the discrepancies in the reported response in bacterial protein synthesis (BPS) to free oil supplementation and further, to see whether

\footnotetext{
* Present address: National Veterinary Research Institute, Vom, Nigeria.
} 
a level of supplementation could be identified that would enhance the efficiency of BPS without reducing $\mathrm{ADOM}_{\mathrm{R}}$.

A preliminary report of these results has been published elsewhere (Ikwuegbu \& Sutton, 1981).

\section{EXPERIMENTAL}

\section{Animals and management}

Three Suffolk $\times$ Scottish half-bred wethers, aged approximately 10 months at the time of surgery and weighing between 35 and $45 \mathrm{~kg}$ were used. They were each fitted with a permanent cannula in the rumen and a re-entrant cannula (Ash, 1962) in the duodenum approximately $50 \mathrm{~mm}$ beyond the pylorus but proximal to the point of entry of the common bile duct. Each sheep received each of the four experimental diets in a random order.

\section{Housing}

All the sheep were kept in individual metabolism crates in the sheep house throughout the experiment. The floor of the crate was made of expanded metal, the front half of which was covered with a rubber mat. The animals had considerable freedom of movement but could not turn around. No artificial light was provided except when collections were being made.

\section{Diets and feeding procedure}

The basal diet was similar to that used by Knight et al. (1978) and was composed of $200 \mathrm{~g}$ hay and $400 \mathrm{~g}$ concentrate mix. The concentrate consisted of $(\mathrm{g} / \mathrm{kg}$ air-dry mix $)$ : rolled barley 884 , soya-bean meal 46 , protected sodium caseinate 46 , copper-free mineral mix (Boots Farmsales Ltd, Witney, Oxon) 14, and sodium sulphate-ammonium molybdate 10. The sodium sulphate-ammonium molybdate was included to reduce the risk of $\mathrm{Cu}$ toxicity (Cammell, 1977). The sodium caseinate was protected by treatment with formaldehyde (MacCormac Products Ltd, Killeshandra, Ireland) and was included because it had also been a component of the diets used in the previous study by Knight et al. (1978). The composition of the hay and concentrate is shown in Table 1.

Raw LSO (Signpost Paints, Haverhill, Suffolk) was used as a supplement in three of the four diets. It was stabilized by an antioxidant, butylated hydroxy-toluene (2,6-ditertbutyl-p-cresol), added to give a concentration of $200 \mathrm{mg} / 1$. LSO was added to the basal concentrate at 13,26 and $40 \mathrm{ml} / \mathrm{d}$ to provide four experimental diets containing $0,20,39$ and $60 \mathrm{~g} \mathrm{LSO} / \mathrm{kg}$ diet respectively.

The basal diet was fed in two equal portions at 06.00 and 18.00 hours. LSO was measured out by volume daily and well mixed by hand into the concentrate mix. Refusals were removed and weighed just before the afternoon feeding. Water was always available.

\section{Experimental routine}

Each period was divided into $42 \mathrm{~d}$. The basal diet was given for the first $5 \mathrm{~d}$ and during this time an inoculum of approximately $100 \mathrm{ml}$ rumen fluid from a sheep on the basal diet was given to all the sheep that had previously received an oil-supplemented diet to encourage re-establishment of protozoa. After this, LSO was introduced gradually over a period of $8 \mathrm{~d}$. A period of $11 \mathrm{~d}$ was allowed for adaptation to treatment and $18 \mathrm{~d}$ for sample collection and measurements. In the sampling period, faeces and urine were collected for the first $8 \mathrm{~d}$ using a harness and bag for collection of the faeces. On day 4, $50 \mathrm{ml}$ rumen fluid were taken every hour for $6 \mathrm{~h}$ and every $2 \mathrm{~h}$ for the next $6 \mathrm{~h}$, using a stainless-steel strainer. The pH was determined immediately. A portion of the rumen fluid used for ammonia determination 
Table 1. The mean dry matter (DM) content and composition of the DM of the hay and the concentrate mix

\begin{tabular}{llc}
\hline & Hay & Concentrates \\
\hline DM (g/kg feed) & 844 & 865 \\
Composition of DM (g/kg DM) & & \\
$\quad$ Organic matter & 916 & 945 \\
Acid-detergent fibre & 368 & 63 \\
Starch & 14 & 495 \\
Nitrogen & $15 \cdot 9$ & 28.6 \\
Gross energy (MJ) & 17.80 & 17.96 \\
\hline
\end{tabular}

was mixed with three drops of concentrated sulphuric acid and stored at $-20^{\circ}$. The remainder was stored at $-20^{\circ}$. A portion $(10 \mathrm{ml})$ of a separate sample of rumen fluid used for protozoa counts was added to $10 \mathrm{ml}$ of a mixture of glycerol-water-formalin $(500: 450: 50$, by vol.) and stored at room temperature. Blood samples were taken from the jugular vein every $3 \mathrm{~h}$ for $12 \mathrm{~h}$ on day 5 . The flow of digesta at the duodenum was determined by taking spot samples of digesta, using chromic oxide paper $(2.5 \mathrm{~g}$ paper containing $0.88 \mathrm{~g}$ $\mathrm{Cr}_{2} \mathrm{O}_{3}$ put into the rumen twice daily) as the marker. Approximately $150 \mathrm{ml}$ duodenal digesta were taken from the proximal cannula on six occasions over $3 \mathrm{~d}$ starting on day 8. The collection of digesta was arranged such that a sample was taken every $2 \mathrm{~h}$ during the $12 \mathrm{~h}$ daytime feeding cycle. Six rumen samples of $100 \mathrm{ml}$ each were taken for 2,4-diaminopimelic acid (DAPA) estimation over $12 \mathrm{~h}$ on day 11 . Bacterial samples were isolated within $3 \mathrm{~h}$ of the last sample being taken using differential centrifugation as described by Smith \& McAllan (1974). For measurement of rumen fiuid kinetics, a single injection of a solution of approximately $100 \mu \mathrm{Ci}{ }^{15} \mathrm{Cr}$-EDTA solution was given at 07.00 hours on day 18 and the decline of radioactivity monitored in samples taken at hourly intervals for $11 \mathrm{~h}$.

\section{Chemical analyses}

Feed samples were dried for $24 \mathrm{~h}$ at $105^{\circ}$ and total duodenal digesta and faeces were freeze-dried for $3 \mathrm{~d}$ for dry matter (DM) content. They were analysed for om by ashing at $550^{\circ}$ for $4 \mathrm{~h}$, for $\mathrm{N}$ by the micro-Kjeldahl technique, for $\alpha$-linked glucose polymers by the method of MacRae \& Armstrong (1968) and for acid-detergent fibre (ADF) by the method of Van Soest (1973). Determination of $\mathrm{Cr}_{2} \mathrm{O}_{3}$ was by the method of Stevenson \& De Langen (1960). Duplicate $2 \mathrm{ml}$ portions of rumen fluid and $0.5 \mathrm{ml}{ }^{15} \mathrm{Cr}$-EDTA infusate were counted for 4 min using an Intertechnique CG4000 gamma spectrometer (Intertechnique Ltd, Uxbridge, Middlesex). Volatile fatty acids (VFA) in rumen samples were determined by gas-liquid chromatography (Sutton \& Johnson, 1969), ammonia in acidified rumen samples by the method of Merry et al. (1982) and plasma urea-N by the method of Marsh et al. (1965). The DAPA content of bacteria and duodenal digesta was determined by ion-exchange chromatography using an Auto-Analyzer (Technicon Instruments $\mathrm{Co}$, Basingstoke, Hants) by the method of Smith et al. (1978) which involves $22 \mathrm{~h}$ hydrolysis in 6 M-hydrochloric acid at $108^{\circ}$. The proportion of duodenal $\mathbf{N}$ present as bacterial $\mathbf{N}$ was calculated as $\mathrm{mg}$ DAPA/g $\mathrm{N}$ in duodenal digesta $\times \mathrm{g} \mathrm{N} / \mathrm{mg}$ DAPA in bacterial samples.

\section{Calculations}

The values were analysed as a randomized block. Linear and quadratic trends were calculated for treatment effects. In the presentation of results the change in the amount or 
Table 2. The mean amounts of gross energy $(M J / d)$ consumed, passing through the duodenum and excreted in the faeces and its digestion in the stomach and total tract in three sheep given a basal diet alone or supplemented with 13,26 or $40 \mathrm{ml}$ linseed oil/d

\begin{tabular}{|c|c|c|c|c|c|c|c|}
\hline & \multicolumn{4}{|c|}{ Linseed oil (ml/d) } & \multirow[b]{2}{*}{ SEM } & \multicolumn{2}{|c|}{ Effects } \\
\hline & 0 & 13 & 26 & 40 & & Linear & Quadratic \\
\hline \multicolumn{8}{|l|}{ Flow (MJ/d) } \\
\hline Food & $9 \cdot 19$ & 9.73 & $10 \cdot 15$ & $10 \cdot 48$ & 0.080 & $* * *$ & NS \\
\hline Duodenum & $5 \cdot 17$ & 5.82 & 7.68 & $7 \cdot 34$ & 0.187 & $* * *$ & $*$ \\
\hline Faeces & $2 \cdot 15$ & $2 \cdot 24$ & 2.64 & $2 \cdot 77$ & 0.098 & $* *$ & NS \\
\hline \multicolumn{8}{|l|}{ Digestion } \\
\hline Stomach & 0.44 & 0.40 & 0.24 & 0.31 & 0.017 & *** & * \\
\hline Total & 0.77 & 0.77 & 0.74 & 0.74 & 0.011 & NS & NS \\
\hline$\frac{\text { Stomach }}{\text { Total }}$ & 0.57 & 0.53 & 0.33 & 0.42 & 0.027 & ** & * \\
\hline
\end{tabular}

NS, not significant.

- $P<0.05,{ }^{* *} P<0.01,{ }^{* * *} P<0.001$.

Table 3. The mean amounts of organic matter $(g / d)$ consumed, passing through the duodenum and excreted in the faeces and its digestion in the stomach and total tract in three sheep given a basal diet alone or supplemented with 13,26 or $40 \mathrm{ml}$ linseed oil/d

\begin{tabular}{|c|c|c|c|c|c|c|c|}
\hline & \multicolumn{4}{|c|}{ Linseed oil $(\mathrm{m} 1 / \mathrm{d})$} & \multirow[b]{2}{*}{ SEM } & \multicolumn{2}{|c|}{ Effects } \\
\hline & 0 & 13 & 26 & 40 & & Linear & Quadratic \\
\hline \multicolumn{8}{|l|}{ Flow $(g / d)$} \\
\hline Food & 479 & 497 & 508 & 521 & 4.7 & **** & NS \\
\hline Duodenum & 238 & 265 & 345 & 323 & $10 \cdot 2$ & $* * *$ & $\because$ \\
\hline Faeces & 101 & 105 & 124 & 129 & $4 \cdot 6$ & $* *$ & NS \\
\hline \multicolumn{8}{|l|}{ Digestion } \\
\hline Stomach & 0.50 & 0.47 & 0.32 & 0.38 & 0.019 & $* * *$ & * \\
\hline Total & 0.79 & 0.79 & 0.76 & 0.75 & 0.010 & $*$ & NS \\
\hline$\frac{\text { Stomach }}{\text { Total }}$ & 0.64 & 0.59 & 0.42 & 0.51 & 0.028 & ** & NS \\
\hline
\end{tabular}

NS, not significant.

* $P<0.05,{ }^{* *} P<0.01,{ }^{* * *} P<0.001$.

proportion of nutrients apparently digested between the mouth and the proximal duodenum is referred to as digestion in the stomach. True digestion was calculated by adding bacterial flow to the amount apparently digested.

\section{RESULTS}

Energy digestion

The effects of LSO supplements on the digestion of energy (Table 2) and oM (Table 3) were very similar and will be considered together. The addition of LSO caused a highly significant $(P<0.001)$ linear reduction in digestibility in the stomach, though the reduction tended to be less with $40 \mathrm{ml}$ than with $26 \mathrm{ml}$ LSO leading to a quadratic $(P<0.05)$ effect also. There was a much smaller reduction in digestibility in the total tract with the result that the proportion of digestion occurring in the stomach also fell linearly $(P<0.01)$.

The amount of ADF flowing to the duodenum increased linearly $(P<0.05)$ with LSO 
Table 4. The mean amounts of acid-detergent fibre $(\mathrm{g} / \mathrm{d})$ consumed, passing through the proximal duodenum and excreted in the faeces and its digestion in the different sites of the digestive tract of three sheep given a basal diet alone or supplemented with 13,26 or $40 \mathrm{ml}$ linseed oil/d

\begin{tabular}{|c|c|c|c|c|c|c|}
\hline & \multicolumn{4}{|c|}{ Linseed oil $(\mathrm{ml} / \mathrm{d})$} & \multirow[b]{2}{*}{ SEM } & \multirow{2}{*}{$\frac{\text { Effect } \dagger}{\text { Linear }}$} \\
\hline & 0 & 13 & 26 & 40 & & \\
\hline \multicolumn{7}{|l|}{ Flow $(\mathrm{g} / \mathrm{d})$} \\
\hline Food & 83 & 84 & 84 & 84 & $1 \cdot 2$ & NS \\
\hline Duodenum & 46 & 60 & 69 & 72 & $3 \cdot 1$ & $*$ \\
\hline Faeces & 37 & 40 & 46 & 49 & $2 \cdot 3$ & * \\
\hline \multicolumn{7}{|l|}{ Digestion } \\
\hline Stomach & 0.44 & 0.28 & 0.18 & 0.14 & 0.035 & $* *$ \\
\hline Total & 0.55 & 0.52 & 0.46 & 0.41 & 0.031 & $*$ \\
\hline$\frac{\text { Stomach }}{\text { Total }}$ & 0.82 & 0.55 & 0.40 & 0.35 & 0.087 & * \\
\hline
\end{tabular}

NS, not significant.

* $P<0.05$, ** $P<0.01$.

$\dagger$ No quadratic effects were significant.

supplementation (Table 4). The increase with the two higher levels of LSO was over $50 \%$ and accounted for approximately one-quarter of the increased flow of oM on these diets. There was also a linear increase in faecal output but, as with the digestion of energy and $\mathrm{OM}$, the reduction in total digestion was smaller than the reduction in digestion in the rumen with the result that the contribution of the stomach to over-all digestion fell linearly $(P<0.05)$ with increasing LSO. Thus a major consequence of the LSO supplementation was that $45-65 \%$ of total ADF digestion occurred in sites distal to the proximal duodenum when LSO was added compared to $18 \%$ on the basal diet.

There was no significant effect of supplementation on digestion of starch ( $\alpha$-linked glucose polymers). Of the average daily intake of $174 \mathrm{~g}$, only $13 \mathrm{~g}(7 \%)$ entered the duodenum and virtually none was excreted in the faeces.

The effect of LSO supplements on rumen VFA are presented in Table 5. Mean total VFA concentrations were not affected by the addition of LSO but there were marked changes in the molar proportions of the major VFA. There were significant $(P<0.05)$ linear decreases in the molar proportions of acetate and butyrate and a linear increase in the proportion of propionate.

\section{Rumen fluid and protozoa numbers}

These values are presented in Table 5. Rumen fluid volume increased significantly $(P<0.05)$ as the concentration of LSO in the basal diet was increased, though only with the two higher concentrations of LSO were the increases, of approximately $26 \%$, significant $(26 \mathrm{ml} / \mathrm{d}$, $P<0.01 ; 40 \mathrm{ml} / \mathrm{d}, P<0.05$ ). Rumen fluid clearance rate was not significantly affected by LSO supplements although it tended to be lower at the higher levels of supplementation. An opposite effect was observed with rumen outflow rate which tended to increase slightly with LSO supplementation.

Protozoa numbers were severely reduced when the concentration of LSO in the basal diet was increased. There were significantly linear $(P<0.001)$ and quadratic trends $(P<0.05)$. The two higher concentrations of LSO almost completely eliminated protozoa from the rumen $(P<0.001)$. Rumen $\mathrm{pH}$ was slightly lower on the LSO-supplemented diets but the effects were not significant. 
Table 5. The mean concentration of total volatile fatty acids $(V F A)(\mathrm{mmol} / \mathrm{l})$ and molar proportions (mmol/mol total VFA) of the major VFA, the volume ( $($ ), clearance rate/h, outflow rate $(l / d), p H$ and protozoa numbers $\left(\times 10^{-4} / \mathrm{ml}\right)$ in the rumen fuid of three sheep given a basal diet alone or supplemented with 13,26 or $40 \mathrm{ml}$ linseed oil/d

\begin{tabular}{|c|c|c|c|c|c|c|c|}
\hline & \multicolumn{4}{|c|}{ Linseed oil (ml/d) } & \multirow[b]{2}{*}{ SEM } & \multicolumn{2}{|c|}{ Effects } \\
\hline & 0 & 13 & 26 & 40 & & Linear & Quadratic \\
\hline Total VFA & $64 \cdot 5$ & $62 \cdot 7$ & $66 \cdot 8$ & $65 \cdot 3$ & $5 \cdot 25$ & NS & NS \\
\hline \multicolumn{8}{|l|}{ VFA proportions } \\
\hline Acetate & 640 & 608 & 536 & 528 & $21 \cdot 3$ & $*$ & NS \\
\hline Propionate & 182 & 261 & 330 & 367 & $45 \cdot 4$ & $*$ & NS \\
\hline$n$-Butyrate & 122 & 76 & 57 & 47 & $12 \cdot 1$ & * & NS \\
\hline Volume & $4 \cdot 3$ & $4 \cdot 6$ & $5 \cdot 5$ & $5 \cdot 4$ & 0.02 & $*$ & NS \\
\hline Clearance rate & 0.062 & 0.063 & 0.055 & 0.053 & 0.0106 & NS & NS \\
\hline Outflow rate & $6 \cdot 4$ & $7 \cdot 0$ & $7 \cdot 3$ & 6.9 & $1 \cdot 00$ & NS & NS \\
\hline $\mathrm{pH}$ & $6 \cdot 62$ & $6 \cdot 35$ & $6 \cdot 41$ & $6 \cdot 48$ & $0 \cdot 123$ & NS & NS \\
\hline Protozoa & 372 & 211 & 9 & 1 & $33 \cdot 2$ & ** & * \\
\hline
\end{tabular}

NS, not significant.

* $P<0.05$, ** $P<0.01$.

Table 6. The mean amounts of nitrogen $(\mathrm{g} / \mathrm{d})$ consumed, passing through the duodenum, excreted and retained and the apparent digestion of nitrogen in three sheep given a basal diet alone or supplemented with 13,26 or $40 \mathrm{ml}$ linseed oil/d

\begin{tabular}{|c|c|c|c|c|c|c|}
\hline & \multicolumn{4}{|c|}{ Linseed oil $(\mathrm{ml} / \mathrm{d})$} & \multirow[b]{2}{*}{ SEM } & \multirow{2}{*}{$\frac{\text { Effects } \dagger}{\text { Linear }}$} \\
\hline & 0 & 13 & 26 & 40 & & \\
\hline Food & $13 \cdot 3$ & $12 \cdot 3$ & 12.6 & 11.9 & 1.08 & NS \\
\hline Duodenum & $11 \cdot 0$ & 11.8 & $17 \cdot 0$ & $14 \cdot 2$ & $1 \cdot 04$ & * \\
\hline Faeces & $3 \cdot 0$ & $3 \cdot 2$ & $3 \cdot 6$ & $3 \cdot 8$ & 0.17 & * \\
\hline Urine & $7 \cdot 2$ & 6.8 & $6 \cdot 1$ & 4.8 & 0.60 & * \\
\hline Retained & $3 \cdot 0$ & $2 \cdot 3$ & 2.9 & $3 \cdot 3$ & 1.21 & NS \\
\hline \multicolumn{7}{|c|}{ Apparent digestion } \\
\hline Stomach & 0.16 & 0.03 & $-0 \cdot 38$ & $-0 \cdot 19$ & 0.127 & * \\
\hline Total & 0.77 & 0.73 & 0.71 & 0.68 & 0.033 & NS \\
\hline
\end{tabular}

NS, not significant.

$* P<0.05$

$\uparrow$ No quadratic effects were significant.

\section{$N$ metabolism}

The over-all $\mathbf{N}$ transactions in the whole animal are shown in Table 6 . There was no significant effect on $\mathrm{N}$ retention in these mature sheep. Excretion of $\mathrm{N}$ in the faeces increased significantly $(P<0.05)$ but the resulting fall in digestibility did not attain significance. There was a linear $(P<0.05)$ fall in $\mathrm{N}$ excretion in urine and the highest concentration of LSO was associated with a reduction of approximately $33 \%$ in urinary $\mathrm{N}$. Flow of $\mathrm{N}$ at the duodenum was increased by over $50 \%(P<0.05)$ when $26 \mathrm{ml}$ LSO were given. At the highest level of supplementation the increase was smaller and non-significant but over-all a linear response was established $(P<0.05)$. Ammonia-N flow averaged $0.9 \mathrm{~g} / \mathrm{d}$ and was unaffected by diet. The pattern of flow of non-ammonia-N (NAN) for the four diets was 
Table 7. Flow of bacterial organic matter (OM) and nitrogen at the duodenum, the true and apparent digestion of $\mathrm{OM}$ in the stomach, and the efficiency of bacterial protein synthesis in three sheep given a basal diet alone or supplemented with 13,26 or $40 \mathrm{ml}$ linseed oil/d

\begin{tabular}{|c|c|c|c|c|c|c|c|}
\hline & \multicolumn{4}{|c|}{ Linseed oil (ml/d) } & \multirow[b]{2}{*}{ SEM } & \multicolumn{2}{|c|}{ Effects } \\
\hline & 0 & 13 & 26 & 40 & & Linear & Quadratic \\
\hline \multicolumn{8}{|l|}{ Bacterial flow $(\mathrm{g} / \mathrm{d})$} \\
\hline OM & 90 & 96 & 115 & 99 & 6.7 & NS & NS \\
\hline $\mathbf{N}$ & $7 \cdot 5$ & $8 \cdot 1$ & $9 \cdot 7$ & $6 \cdot 7$ & 0.56 & NS & NS \\
\hline \multicolumn{8}{|l|}{ OM digested in stomach $(\mathrm{g} / \mathrm{d})$} \\
\hline Apparent $\left(\mathrm{ADOM}_{R}\right)$ & 240 & 232 & 163 & 198 & $9 \cdot 5$ & $* *$ & $*$ \\
\hline True $\left(\right.$ TDOM $\left._{R}\right)$ & 330 & 328 & 277 & 297 & 14.5 & NS & NS \\
\hline $\begin{array}{l}\text { True digestion of om in stomach } \\
\text { Efficiency of bacterial } \\
\text { protein synthesis }\end{array}$ & $0 \cdot 69$ & $0 \cdot 66$ & 0.55 & 0.57 & 0.027 & $*$ & NS \\
\hline $\mathrm{g} \mathrm{N} / \mathrm{kg} \wedge \mathrm{ADOM}_{\mathrm{R}}$ & 32 & 35 & 59 & 34 & 2.9 & NS & $* * *$ \\
\hline $\mathrm{g} \mathrm{N} / \mathrm{kg}$ TDOM$_{\mathrm{R}}$ & 23 & 25 & 35 & 22 & $1 \cdot 3$ & NS & *** \\
\hline
\end{tabular}

NS, not significant.

- $P<0.05$, ** $P<0.01$, *** $P<0.001$.

Table 8. The mean concentration (mmol/l) of ammonia in rumen and duodenal fluid and of urea in blood plasma in three sheep given a basal diet alone or supplemented with 13, 26 or $40 \mathrm{ml}$ linseed oil/d

\begin{tabular}{|c|c|c|c|c|c|c|}
\hline & \multicolumn{4}{|c|}{ Linseed oil (ml/d) } & \multirow[b]{2}{*}{ SEM } & \multirow{2}{*}{$\frac{\text { Effects } \dagger}{\text { Linear }}$} \\
\hline & 0 & 13 & 26 & 40 & & \\
\hline Rumen ammonia & $16 \cdot 7$ & $9 \cdot 3$ & $7 \cdot 1$ & $6 \cdot 2$ & $1 \cdot 53$ & ** \\
\hline Duodenal ammonia & $8 \cdot 2$ & 5.9 & $4 \cdot 8$ & $5 \cdot 1$ & 0.95 & NS \\
\hline Plasma urea & $5 \cdot 5$ & $4 \cdot 5$ & $4 \cdot 6$ & $3 \cdot 2$ & 0.93 & NS \\
\hline
\end{tabular}

NS, not significant.

** $P<0.01$.

$\dagger$ No quadratic effects were significant.

therefore similar to that of total $\mathrm{N}$ and averaged $10 \cdot 0,10 \cdot 9,15.9$ and $13.4 \mathrm{~g} / \mathrm{d}$ for the four diets respectively.

Aspects of the effects of the LSO on bacterial synthesis are shown in Table 7. Estimates of bacterial synthesis were based on the use of DAPA as the marker and average values for mg DAPA/g bacterial $N$ from rumen samples varied between 40 and 43 , well within the published range. The only level of LSO supplementation to affect bacterial om or $\mathrm{N}$ flow significantly $(P<0.05)$ was $26 \mathrm{ml} / \mathrm{d}$ which resulted in increases of slightly less than $30 \%$. The effects of LSO on the amount of oM truly digested in the rumen $\left(\mathrm{TDOM}_{\mathrm{R}}\right)$ were similar to the effects on apparent digestion and a significant $(P<0.05)$ linear decrease in true digestibility was established. Supplementation with LSO resulted in large increases in the efficiency of BPS $\left(85 \%\right.$ when based on $\mathrm{ADOM}_{R}$ and $52 \%$ when based on $\mathrm{TDOM}_{R}$ ) when $26 \mathrm{ml} / \mathrm{d}$ were used but no significant increases at the other levels and this is reflected by the highly significant $(P<0.001$ and $P<0.01)$ quadratic relationships.

The concentrations of ammonia in rumen and duodenal fluid and of urea in blood plasma fell with increasing LSO, though only in the instance of rumen ammonia was a significant $(P<0.01)$ linear trend established (Table 8). 


\section{DISCUSSION}

The method of measuring digesta flow at the duodenum in this experiment was spot sampling from re-entrant cannulas with $\mathrm{Cr}_{2} \mathrm{O}_{3}$ as the marker. The case for using 'dual-phase' markers with spot sampling was discussed at length by Faichney (1975) but this was for use in conjunction with simple cannulas which are likely to yield samples that are not representative of the digesta flowing. When re-entrant cannulas are used, as in the present study, none of the digesta can by-pass the sampling site, so it is reasonable to conclude that $\mathrm{Cr}_{2} \mathrm{O}_{3}$, when administered in a form that allows its relatively steady release from the rumen, will be an adequate if not perfect marker. Corse \& Sutton (1971) found no difference in estimates of DM flow between spot samples and samples obtained by total collections from re-entrant cannulas in sheep when $\mathrm{Cr}_{2} \mathrm{O}_{3}$ was the marker. The close similarity of the values on the basal diet in the present experiment to the mean values recently published by the Agricultural Research Council (1980) for $\mathrm{ADOM}_{\mathrm{R}}: \mathrm{ADOM}_{\text {Total tract }}$ (0.64 this paper v. 0.65 $A R C)$ and for the efficiency of protein synthesis ( $g$ bacterial or microbial N/ $\mathrm{kg} \mathrm{ADOM}$ ) (32 this paper $v .30 \mathrm{ARC}$ ) is strong evidence that the technique yielded reasonable estimates of the flow of the major constituents of digesta reported here.

The amount of oM truly digested in the rumen $\left(\mathrm{TDOM}_{\mathrm{R}}\right.$ ) was estimated by adding to the amount of OM apparently digested $\left(\mathrm{ADOM}_{\mathrm{R}}\right)$ the amount of bacterial oM as calculated from the DAPA : OM concentration in bacterial samples from the rumen and using DAPA as the bacterial marker at the duodenum. This under-estimates $\operatorname{TDOM}_{R}$ by the amount of protozoal ом but if, as seems probable, protozoal oм constitutes only $25 \%$ or less of microbial ом at the duodenum on conventional diets (Weller \& Pilgrim, 1974; Harrison et al. 1979) then the under-estimate of $\mathrm{TDOM}_{\mathrm{R}}$ would be only about $10 \%$ on the basal diet and far less on the diets supplemented with LSO, particularly at the two higher levels when protozoa were almost eliminated. There are other sources of error in estimating $\operatorname{TDOM}_{R}$ which have been extensively discussed by Czerkawski (1978) but the method used in the present study probably yields a reasonable approximation to the true value.

\section{Changes in energy digestion}

The principal aim of this work was to examine the effects on om digestion and BPS in the rumen of increasing levels of LSO added to the diet with a view to establishing an optimal level of supplementation for maximizing the supply of bacterial protein to the intestines.

The results confirmed those of previous experiments (Devendra \& Lewis, 1974; Knight et al. 1978) which showed that the inclusion of free oils in the diet of sheep reduced the digestion of energy and ом in the rumen. The maximum depression, of approximately $34 \%$, in the proportion of digestible ом apparently digested in the stomach in the present studies was very similar to that reported by Knight et al. (1978) with $67 \mathrm{~g}$ free LSO or coconut oil $/ \mathrm{kg}$ diet but considerably greater than the $4-9 \%$ depression found by Devendra \& Lewis (1974) when two diets were supplemented with $80 \mathrm{~g}$ maize oil or tallow $/ \mathrm{kg}$ diet. In the present experiment, increasing the concentration of LSO in the diet did not have a consistent effect on the reduction in om digestion in the stomach. The greatest depression occurred with $39 \mathrm{~g} \mathrm{LSO} / \mathrm{kg}$ diet $(26 \mathrm{ml} \mathrm{LSO} / \mathrm{d})$ whereas the effect with the highest level of oil $(67 \mathrm{~g} \mathrm{LSO} / \mathrm{kg} \operatorname{diet}(40 \mathrm{ml} \mathrm{LSO} / \mathrm{d}))$ was smaller, though not significantly so, and it was also smaller than the depression found by Knight et al. (1978) at a similar level of inclusion.

The reduction in OM digestibility was associated with a marked depression in ADF digestion in the stomach. This is consistent with the reduced digestibility of cellulose or crude fibre reported by many workers (Brooks et al. 1954; Czerkawski et al. 1966; Devendra \& Lewis, 1974; Kowalczyk et al. 1977) when free oils were added to various diets. A major effect of the oil was to shift the site of digestion of digestible ADF to the intestines, presumably the caecum, with the result that the reduction in over-all digestion was small. 
The absence of any charge in the concentration of VFA in the rumen is surprising in view of the large reduction in $\mathrm{OM}$ digestion and the $25 \%$ increase in rumen fluid volume, but it is in agreement with the results of Knight (1980). However, in other experiments (Czerkawski et al. 1975; Devendra, 1975; Sutton et al. 1975) a variety of free oils reduced VFA concentrations. In view of the large reduction in $\mathrm{ADOM}_{R}$ there is little doubt that the production of VFA was reduced by the LSO in the present studies even though their concentration remained unchanged. The changes in molar proportions of VFA in response to the free oils were similar to those reported by many other workers and their extent was closely related to the amount of oil fed.

Protozoa were almost completely eliminated from the rumen at the two higher levels of LSO supplementation. This defaunating effect of oils has been reported previously (Purser \& Moir, 1966; Czerkawski et al. 1975; Knight et al. 1978) and is probably due to the fatty acids rather than the oil itself (Czerkawski, 1973; Van Nevel \& Demeyer, 1981). The consequences of defaunation are still a subject for much debate but, in the context of the present study, it is probable that it contributed to the reduced fibre digestion and, as discussed later, the changes in the efficiency of bacterial protein synthesis (see Demeyer, 1981).

\section{Bacterial synthesis}

As in the studies of Knight et al. (1978), the efficiency of BPS was increased by addition of LSO to the diet. However, in the present experiment the increase was approximately $80 \%$ and only occurred with $39 \mathrm{~g} \mathrm{LSO} / \mathrm{kg}$ diet whereas with $60 \mathrm{~g} \mathrm{LSO} / \mathrm{kg}$ diet, which Knight et al. (1978) found to cause an increase of $180 \%$, no increase was detected. Czerkawski et al. (1975) calculated that even though there was an increase in bacterial numbers associated with a decrease in protozoal numbers as the concentration of LSO in the diet of sheep was increased to $100 \mathrm{~g} / \mathrm{kg}$ diet, there was a fall in the amount of BPS as calculated from DAPA concentrations and outflow rates of rumen fluid. Sutton et al. (1975) found no change in MPS when sheep were given a diet containing $33 \mathrm{~g}$ cod liver oil $/ \mathrm{kg}$ diet.

Thus although the experiment did succeed in defining a level of LSO inclusion that maximized the supply of bacterial protein, it is quite apparent that the response to free oil supplementation is very variable. A probable explanation for the variability of response is provided by a recent investigation by Van Nevel \& Demeyer (1981). From in vitro studies of the effect of methane inhibitors on the metabolism of rumen microbes, they concluded that LSO hydrolysate could either increase or decrease MPS depending on the net effect of two opposing factors. They argued that its direct effect on bacteria was to depress protein synthesis but that this effect might be masked because it also removed protozoa which, as they had shown earlier (Demeyer \& Van Nevel, 1979) would result in an enhancement of both total and net synthesis. Such a theory fits the results of the present study well. The lowest level of LSO that virtually eliminated protozoa from the rumen $(26 \mathrm{ml} / \mathrm{d})$ coincided with the greatest efficiency of BPS. At still higher additions of LSO $(40 \mathrm{ml} / \mathrm{d})$ BPS was reduced, presumably because no further appreciable reduction in protozoal numbers was possible and the inhibitory effect of the LSO on bacterial metabolism was the dominant response. On the basis of this theory, the net effect of such agents as free oils on MPS is likely to remain highly unpredictable, depending as it does on the net effect of opposing responses.

An additional complication is that lipid supplements are normally provided in the form of the oil or fat, as in the present study, yet it is the free fatty acid that appears to be the toxic agent (Henderson, 1973; Maczulac et al. 1981). Thus the effect of dietary lipids on microbial metabolism probably depends to a considerable degree on the rate of hydrolysis of the supplement.

Many other factors have been implicated in observed variations in the efficiency of MPS. 
Ishaque et al. (1971) correlated a high efficiency of MPS with high molar proportions of propionate when sheep were given a high-concentrate diet of hay, barley and maize. Harrison et al. (1976) found that high fluid clearance rates brought about by intra-ruminal infusion of artificial saliva were associated with increased efficiency of MPS but also with high molar proportions of acetate and low proportions of propionate. In the present experiment the highest efficiency of BPS, found with $26 \mathrm{ml} \mathrm{LSO} / \mathrm{d}$, was associated with an increase in propionate and a decrease (non-significant) of approximately $11 \%$ in rumen clearance rate, yet at still higher proportions of propionate the efficiency of BPS fell. Kennedy et al. (1976) suggested that a high rumen clearance rate was more important in increasing MPS than was manipulating an increase in the molar proportion of propionate. It is clear that the relationships between the efficiency of MPS, rumen VFA proportions and fluid clearance rates are complex and it seems probable that on these diets, the major factor influencing BPS was the LSO itself.

The effect of the two higher levels of LSO on the flow of NAN at the duodenum was greater than the effect on bacterial N flow. With 26 and $40 \mathrm{ml} \mathrm{LSO} / \mathrm{d}$, the flow of NAN exceeded the flow of bacterial $\mathrm{N}$ by 6.2 and $6.7 \mathrm{~g} / \mathrm{d}$ respectively, whereas with 0 and $13 \mathrm{ml} \mathrm{LSO} / \mathrm{d}$ the difference was only 2.5 and $2.8 \mathrm{~g} / \mathrm{d}$ respectively. This suggests that LSO reduced feed protein degradability by approximately $4 \mathrm{~g} \mathrm{~N} / \mathrm{d}$ though it is also possible that part of the increase reflected a greater endogenous secretion of $\mathrm{N}$ due to the higher flow of undigested fibre from the rumen.

It must be concluded that addition of free LSO to a mixed diet is likely to reduce the digestion of ом, particularly fibre, the numbers of protozoa, the concentration of ammonia, the ratio of acetic acid to propionic acid and possibly protein degradability in the rumen and that the response is broadly dose-related. Unfortunately, the potentially important effect on MPS is much less predictable and does not bear a simple relationship to the level of inclusion of oil. It must further be borne in mind that in the present experiment and that of Knight et al. (1978), free oil was stirred by hand into the loose concentrate mix daily. Responses may well be different if the oil is incorporated into a pellet as in the studies of Czerkawski et al. (1975) and more normal commercial practice.

The authors are grateful to Dr D. S. Parker for helpful discussions during the course of this work, Dr H. L. Buttle and Mr D. Hathorn for surgical preparation of the animals, Mrs R. J. Fulford for assistance with statistical analyses and Messrs D. J. Napper, E. G. Davies and J. M. Willis for care of the experimental animals. O.A.I. gratefully acknowledges financial support by the Federal Government of Nigeria.

\section{REFERENCES}

Agricultural Research Council (1980). The Nutrient Requirements of Ruminant Livestock. Slough: Commonwealth Agricultural Bureaux.

Ash, R. W. (1962). Anim. Prod. 4, 309.

Brooks, C. C., Garner, G. B., Gehrke, C. W., Muhrer, M. E. \& Pfander, W. H. (1954). J. Anim. Sci. 13, 758.

Cammell, S. B. (1977). Tech. Rep. Grassld Res. Inst. no, 24, p. 4.

Corse, D. A. \& Sutton, J. D. (1971). Proc. Nutr. Soc. 30, 18 A.

Czerkawski, J. W. (1973). J. agric. Sci., Camb. 81, 517.

Czerkawski, J. W. (1978). J. Dairy Sci. 61, 1261.

Czerkawski, J. W., Blaxter, K. L. \& Wainman, F. W. (1966). Br. J. Nutr. 20, 485.

Czerkawski, J. W., Christie, W. W., Breckenridge, G. \& Hunter, M. L. (1975). Br. J. Nutr. $34,25$.

Demeyer, D. I. (1981). Agric. and Environ. 6, 295.

Demeyer, D. I. \& Van Nevel, C. J. (1979). Br. J. Nutr. 42, 515.

Devendra, C. (1975). Mal. Agric. Res. 4, 117.

Devendra, C. \& Lewis, D. (1974). Mal. Agric. Res. 3, 228.

Faichney, G. J. (1975). In Digestion and Metabolism in the Ruminant, p. 277 [I. W. McDonald and A. C. I. Warner, editors]. Armidale, NSW: University of New England. 
Harrison, D. G., Beever, D. E. \& Osbourn, D. F. (1979). Br. J. Nutr. 41, 521.

Harrison, D. G., Beever, D. E., Thomson, D. J. \& Osbourn, D. F. (1976). J. Sci. Fd Agric. $27,617$.

Henderson, C. (1973). J. agric. Sci., Camb. 81, 107.

Ikwuegbu, O. A. \& Sutton, J. D. (1981). Proc. Nutr. Soc. 40, 111 A

Ishaque, M., Thomas, P. C. \& Rook, J. A. F. (1971). Nature, New Biol. 231, 253.

Kennedy, P. M., Christopherson, R. J. \& Milligan, L. P. (1976). Br. J. Nutr. 36, 231.

Knight, R. (1980). Rumen lipid synthesis. PhD thesis, University of Reading.

Knight, R., Sutton, J. D., McAllan, A. B. \& Smith, R. H. (1978). Proc. Nutr. Soc. 37, 14 A

Kowalczyk, J., Orskov, E. R., Robinson, J. J. \& Stewart, C. S. (1977). Br. J. Nutr. 37, 251.

MacRae, J. C. \& Armstrong, D. G. (1968). J. Sci. Fd Agric. 19, 578.

Maczulac, A. E., Dehority, B. A. \& Palmquist, D. L. (1981). Appl. Environ. Microbiol. 42, 856.

Marsh, W. H., Fingerhut, B. \& Miller, H. (1965). Clin. Chem. 11, 624.

Merry, R. J., Smith, R. H. \& McAllan, A. B. (1982). Br. J. Nutr. 48, 305.

Purser, D. B. \& Moir, R. J. (1966). J. Anim. Sci. 25, 668.

Smith, R. H. \& McAllan, A. B. (1974). Br. J. Nutr. 31, 27.

Smith, R. H., McAllan, A. B., Hewitt, D. \& Lewis, P. E. (1978). J. agric. Sci., Camb. 90, 557.

Stevenson, A. E. \& De Langen, H. (1960). N.Z. J. agric. Res. 3, 314.

Sutton, J. D. \& Johnson, V. W. (1969). J. agric. Sci., Camb. 73, 459.

Sutton, J. D., Smith, R. H., McAllan, A. B., Storry, J. E. \& Corse, D. A. (1975). J. agric. Sci., Camb. 84, 317.

Van Nevel, C. J. \& Demeyer, D. I. (1981). Arch. Tierernahr. 31, 141.

Van Soest, P. J. (1973). J. Ass. Off. analyt. Chem. 56, 781.

Weller, R. A. \& Pilgrim, A. F. (1974). Br. J. Nutr. 32, 341. 